Journal of Clinical Investigation

Vol. 42, No. 9, 1963

\title{
IN VITRO ASSAY FOR HUMAN INTRINSIC FACTOR*
}

\author{
By LOUIS IV. SULLIVAN, VICTOR HERBERT, AND WILLIAM B. CASTLE \\ (From the Thorndike Memorial Lahoratory and Second and Fourth [Harvard] Medical \\ Scricics, Boston City Hospital, and the Department of Mcdicine, Hararard \\ Mcdical Sihool, Boston, Mass.)
}

(Submitted for publication December 14, 1962; accepted May 23, 1963)

More than three decades ago, it was discovered that normal human gastric juice contained an "intrinsic factor" lacking in the gastric juice of patients with pernicious anemia (1). Certain characteristics of this gastric intrinsic factor have been determined, such as its lability to heat (2) and to incubation below $\mathrm{pH} 3.5$ (3) and its stability to moderately alkaline $\mathrm{pH}$ (4). Moreover, the function of intrinsic factor is inhibited by moderate acidity of the intestinal milieu (insufficient to destroy intrinsic factor) whether in vivo $(5,6)$ or in vitro $(7)$.

Human intrinsic factor has not yet been isolated in pure form. A major hindrance in such efforts has been that the only reliable assay for intrinsic factor required the use of human subjects. Until 1952, this consisted in therapeutic trial, evaluated principally by comparative reticulocyte responses (8) in patients with untreated pernicious anemia. Subsequently, most assays have been performed by comparing the absorption of radioactive vitamin $\mathrm{B}_{12}$ fed alone and then with the intrinsic factor preparation to be assayed. This assay can be carried out on patients with either untreated or treated pernicious anemia and requires measurement of the amount of radioactivity in stool (9), urine (10), liver (11), plasma (12), or the whole body $(13,14)$. A simple in vitro assay for human intrinsic factor has long been sought.

Based on the finding (15) that vitamin $B_{12}$ uptake by rat-liver slices was enhanced by hog intrinsic factor concentrate (HIFC), in vitro assays for hog intrinsic factor were reported using liver slices (16) and liver homogenates $(17,18)$. However, because of uncertain physiologic correlations, occasional failure of the systems to

\footnotetext{
* This study was supported in part by research grants from the National Institutes of Health, U. S. Public Health Service (A-795 and A-3853), the National Vitamin Foundation, and Eli Lilly and Co.
}

detect intrinsic factor in gastric juices containing free acid (19), relative insensitivity to human intrinsic factor, and the necessity of two separate incubations, these assays have not found wide use in the study of human intrinsic factor. Nevertheless, a liver homogenate assay procedure (20) has proved useful in helping to prepare one of the purest forms of commercial hog intrinsic factor concentrate yet available (21).

Wilson and Strauss $(22,23)$ and, subsequently, Wolff and Nabet (24) reported that vitamin $\mathrm{B}_{12}$ uptake by everted sacs of guinea pig ileum is facilitated by human intrinsic factor, and proposed this technique as an in vitro assay. Guineapig ileum is responsive to intrinsic factor from many species (22). Because of variations in the vitamin $B_{12}$ uptake by different everted ileal sacs from the same animal, as well as because of differences between preparations from different animals, it was necessary for Wolff and Nabet to use one sac from each of ten guinea pigs for one human intrinsic factor assay (24). Boass and Wilson subsequently reported an assay for rat and hamster intrinsic factor, using many thin rings of hamster intestine (25) in each sample to reduce variability among samples.

The present study sought the advantage of using pooled lots of homogenized guinea-pig intestinal mucosa $(7,26)$ to circumvent the variabilities of the rat liver and guinea-pig ileum everted sac systems. This homogenate possesses these advantages: 1) it eliminates variations in the activity of the mucosa of different intestinal segments from the same or from different animals; 2) a single sample of homogenate can serve as a control for a number of experimental flasks ; and 3) large amounts of homogenate can be prepared and frozen in portions until used, eliminating the need for preparing material for each assay and making possible repeated assays with portions of the same substrate. The first two advantages, 
but not the third, may be obtained by using intact mucosal cells $(27)$ or rings of intestinal mucosa $(25,28)$. Rings, however, introduce the problem of nonspecific serosal uptake (28). Although intact rat intestinal mucosal cells were found to be useful for assay of rat intrinsic factor and rings of hamster intestine were useful for assay of rat and hamster intrinsic factor, these systems were not successfully used to assay human intrinsic factor $(25,27,28)$ as would be expected because of the relatively high degree of species specificity of these systems (22). The successful use of homogenates of guinea pig intestinal mucosa as an assay for human and hog intrinsic factor forms the basis of the present report.

\section{MATERIALS AND METHODS}

$C o^{57}$-labeled vitamin $B_{12}$. Different lots of $\mathrm{Co}^{57}$-labeled vitamin $B_{12}$ of varying specific activity (4.6 to $19.9 \mu \mathrm{c}$ per $\mu \mathrm{g})^{1}$ were added to sufficient nonradioactive $B_{12}$ and $0.9 \%$ $\mathrm{NaCl}$, so that final concentration of $\mathrm{Co}^{57} \mathrm{~B}_{12}$ was 10,000 picograms $(\mathrm{pg})^{2}$ per $\mathrm{ml}$ with specific activity varying from $0.04 \mu \mathrm{c}$ per $\mathrm{ml}$ to $0.06 \mu \mathrm{c}$ per $\mathrm{ml}$. In our well-type scintillation counter, we obtained approximately $8 \mathrm{cpm}$ per $\mathrm{pg}$ of $\mathrm{Co}^{57} \mathrm{~B}_{12}$ of the lower specific activity. In the tables, the uptake of radioactive vitamin $B_{12}$ has been expressed as picograms per portion of about $200 \mathrm{mg}$ wet homogenate unless otherwise specified.

Guinea-pig small-intestinal mucosa homogenate. Nonfasting, 200- to $300-\mathrm{g}$, white, male guinea pigs were sacrificed in dozen lots. The small intestine, which averaged $180 \mathrm{~cm}$ in length, was transected at the pylorus, stripped free of its mesenteric attachment, and transected at its ileal end. The upper half of the small intestine was discarded, since the lower half exhibits the greatest degree of intrinsic factor-facilitated vitamin $B_{12}$ uptake (23). The lower half was rinsed with $0.9 \% \mathrm{NaCl}$ from a 100 $\mathrm{ml}$ syringe until the effluent was clear and free of particulate matter. It was then cut into segments 8 to $10 \mathrm{~cm}$ long. Each segment was placed on Parafilm, held at one end with forceps, and the mucosa was expressed by running a metal spatula along the length of the serosal surface while applying gentle pressure (30). The pooled mucosal scrapings from 12 guinea pigs (wet weight, 22 to $24 \mathrm{~g}$ ) were added to $300 \mathrm{ml}$ cold saline $(25 \mathrm{ml}$ per guinea pig) and homogenized for 30 seconds in a Waring Blendor. The homogenate suspension was pipetted into 24 equal samples in test tubes and centrifuged in the cold for 10 minutes at $2,000 \times g$. The supernatant fluid was dis-

1 Kindly supplied by Dr. Elmer Alpert of Merck Sharp \& Dohme Research Laboratories, West Point, Pa.

2 One picogram $(\mathrm{pg})=$ one micromicrogram $(\mu \mu \mathrm{g})=$ $10^{-12} \mathrm{~g}$. Prefix approved by International Union of Pure and Applied Physics (29). carded, and the homogenate pellet was kept at $-20^{\circ} \mathrm{C}$ until used.

Lyophilized, acetone-w'ashed homogenate was prepared from the fresh mucosal homogenate obtained after centrifugation at $2,000 \times g$, by previously described lyophilization methods (20), and stored at room temperature until used. Approximately 1.5 to $1.7 \mathrm{~g}$ of lyophilized substance was obtained from each lot of 12 guinea pigs. Seven $\mathrm{mg}$ of lyophilized substance was used for each assay specimen.

Lyophilized homogenate-KRT buffer- $B_{12}$ was prepared by mixing portions of lyophilized homogenate with KrebsRinger-Tris buffer, $\mathrm{pH} 7.4$, containing $10 \mathrm{mM} \mathrm{CaCl}_{2}$ (16), and $\mathrm{Co}^{57} \mathrm{~B}_{12}$ in ratios of $7 \mathrm{mg}: 5 \mathrm{ml}: 0.5 \mathrm{ml}(5,000 \mathrm{pg})$, respectively, and lyophilizing this mixture. For assay, 12 $\mathrm{ml}$ of deionized water was added to 2 portions of the lyophilized substance for each unknown sample.

National Formulary intrinsic factor concentrate refercnce standard $(N F I F)(31)$ no. 6043 was obtained from the National Formulary of the American Pharmaceutical Association ( 1 test unit $=50 \mathrm{mg}$ ). For the in vitro system, $25 \mathrm{mg}$ of this hog intrinsic factor concentrate was dissolved in $10 \mathrm{ml}$ of $0.9 \% \mathrm{NaCl}(125 \mu \mathrm{g}$ NFIF per 0.05 $\mathrm{ml}$ saline) and stored at $-20^{\circ} \mathrm{C}$ until used.

Human gastric juices were obtained with continuous nasogastric suction under basal conditions and with augmented histamine stimulation in fasting subjects as described by Kay (32). Salivary contamination was minimized by having the subjects expectorate into a basin during the collection periods. Each specimen was measured and filtered through two layers of cheesecloth, and its $\mathrm{pH}$ was determined. Titration to $\mathrm{pH} 11$ was accomplished with $10 \%$ potassium hydroxide to destroy peptic activity (4). After 20 minutes, the specimen was back-titrated to $\mathrm{pH} 7$ with $0.1 \mathrm{~N}$ sulfuric acid and then stored at $-20^{\circ} \mathrm{C}$ until assayed.

In vitro assay system. Each sample of gastric juice or NFIF standard was assayed in duplicate in 20-ml Griffin beakers. For every six samples (three duplicates) one sample of frozen intestinal mucosa homogenate was thawed and reconstituted with $6 \mathrm{ml}$ of $0.9 \% \mathrm{NaCl}$. Since two frozen samples of homogenate were made from the distal half of the small intestine of each guinea pig, material for 12 assay samples (six duplicate pairs) was derived from each animal.

To each beaker were added in sequence: $5 \mathrm{ml} \mathrm{KRT}$ buffer, $1 \mathrm{ml}$ homogenate suspension (or $7 \mathrm{mg}$ of lyophilized intestinal mucosa homogenate), the gastric juice to be assayed $(0.1 \mathrm{ml}$, unless otherwise specified), and $0.5 \mathrm{ml}$ $\mathrm{Co}^{57} \mathrm{~B}_{12}$ solution $(5,000 \mathrm{pg})$. In addition to the unknown gastric juices, duplicate $0.1-\mathrm{ml}$ saline controls and 0.05 $\mathrm{ml}(125 \mu \mathrm{g})$-NFIF standards were included in each group of assays. To assure uniformity of suspension of frozen homogenate after thawing, we agitated it for 3 to 5 seconds in a Waring Blendor after adding $6 \mathrm{ml}$ of $0.9 \% \mathrm{NaCl}$ per sample.

In studies of $\mathrm{pH}$ dependence, the buffer used consisted of 9 parts Krebs-Ringer solution (33), brought to appropriate $\mathrm{pH}$ with 1 part $0.05 \mathrm{M}$ Tris-acid maleate$\mathrm{NaOH}$ buffer (34). 
All samples were gently agitated at a rate of 90 cycles per minute for 30 minutes at room temperature in a Dubnoff metabolic shaker. The homogenate was then precipitated by centrifugation at $2,000 \times g$ for 10 minutes. The supernatant fluid was discarded, after which the homogenate was suspended in, and centrifuged from, 10 $\mathrm{ml}$ and then $3 \mathrm{ml}$ of $0.9 \% \mathrm{NaCl}$ containing $10 \mathrm{mM} \mathrm{CaCl}_{2}$. After the supernatant fluid was decanted, the radioactivity in the homogenate pellet was determined in a well-type scintillation detector. The counts per minute of duplicate samples were averaged and converted to picograms of $\mathrm{B}_{12}$. Differences between duplicates were usually less than $10 \%$.

Clinical (in vivo) assay system. The intrinsic factor activities of certain samples were determined in pernicious anemia patients, in remission, by the modification of the Schilling test adopted as standard by the National Formulary of the U.S.A. (31), using either $30 \mathrm{ml}$ of the unknown gastric juice, or $50 \mathrm{mg}$ of NFIF, and $2 \mu \mathrm{g}$ of $\mathrm{Co}^{60} \mathrm{~B}_{12}$.

\section{RESULTS}

A typical assay is shown in Table I. To correct for nonspecific uptake of $\mathrm{B}_{12}$ into the homogenate, a saline control was included. There was a fourfold or greater enhancement of $\mathrm{B}_{12}$ uptake in this experiment by intrinsic factor, as shown by the last column. Gastric juice from a patient with pernicious anemia did not enhance $\mathrm{B}_{12}$ uptake. The NFIF was included as a reference standard for the in vitro activity of the unknown human gastric juices by analogy with its similar use as a reference standard for the in vivo activity of commercial hog intrinsic factor concentrates (31).

Reproducibility of assay. In an experiment consisting of 20 assays of equal samples of the same normal gastric juice, the average counts per minute for the group was 202, with 19.6 SD, and a coefficient of variation of 9.7 (data not shown).
The average of the saline controls was $36 \mathrm{cpm}$, with $4 \mathrm{SD}$. In a series of six different assays consisting of four samples of the same normal gastric juice, the coefficients of variation were $2.8,1.8,3.3,3.0,6.9$, and 5.2 , respectively. The variability between assays affected the NFIF and saline controls in parallel fashion, so that the ratio of $\mathrm{B}_{12}$ uptake of sample to $\mathrm{B}_{12}$ uptake of control showed less variation than did the absolute number of picograms of $B_{12}$ taken up by different homogenates.

Effect of concentration of intrinsic factor. To determine a reliable concentration of gastric juice for use in the assay system, various amounts of gastric juice from normal volunteers, patients with normal serum $B_{12}$ levels, and patients with pernicious anemia were assayed, as were various concentrations of NFIF. Figure 1 records the results of several experiments. Increasing amounts of normal gastric juice, up to $0.1 \mathrm{ml}$, resulted in increased $\mathrm{B}_{12}$ uptake by the homogenate. In the three specimens assayed in concentrations greater than $0.1 \mathrm{ml}$, there was only slightly greater enhancement at $0.2 \mathrm{ml}$ in two specimens and a slight decline in $\mathrm{B}_{12}$ uptake in the third specimen. At $0.3 \mathrm{ml}$, the enhancement was identical to that obtained with $0.2 \mathrm{ml}$ of gastric juice. Increased amounts of NFIF up to $0.05 \mathrm{ml}$ caused increased $\mathrm{B}_{12}$ uptake, which reached a plateau between 0.05 and $0.5 \mathrm{ml}$ and fell moderately at $1.0 \mathrm{ml}$. This reduced effect of excess intrinsic factor has previously been noted in liver slices (16) and everted sacs of rat small intestine (17). Concentrations of gastric juice and NFIF of $0.1 \mathrm{ml}$ and $0.05 \mathrm{ml}$ $(125 \mu \mathrm{g})$, respectively, were selected for routine use on the basis of the findings noted in Figure 1.

TABLE I

Standard assay for human and hog intrinsic factor activity with guinea-pig intestinal mucosa homogenate

\begin{tabular}{|c|c|c|}
\hline Source of intrinsic factor & $\begin{array}{l}\text { B12 Uptake by } \\
\text { homogenate* }\end{array}$ & $\frac{\mathrm{B}_{12} \text { Uptake of sample }}{\mathrm{B}_{12} \text { uptake of control }}$ \\
\hline & $p g$ & \\
\hline Normal volunteer $\dagger$ & 72 & 4.5 \\
\hline Pernicious anemia patient $\dagger$ & 17 & 1.1 \\
\hline Folic acid-deficient patient $\dagger$ & 59 & 3.7 \\
\hline NFIF+ & 80 & 5.0 \\
\hline Saline control & 16 & 1.0 \\
\hline
\end{tabular}

* Vitamin $B_{12}, 5,000$ picograms (pg), and $300 \mathrm{mg}$ homogenate added to each beaker.

† Gastric juice, $0.1 \mathrm{ml}$.

$\ddagger$ National Formulary hog intrinsic factor concentrate reference standard, lot $6043,125 \mu \mathrm{g}$. 


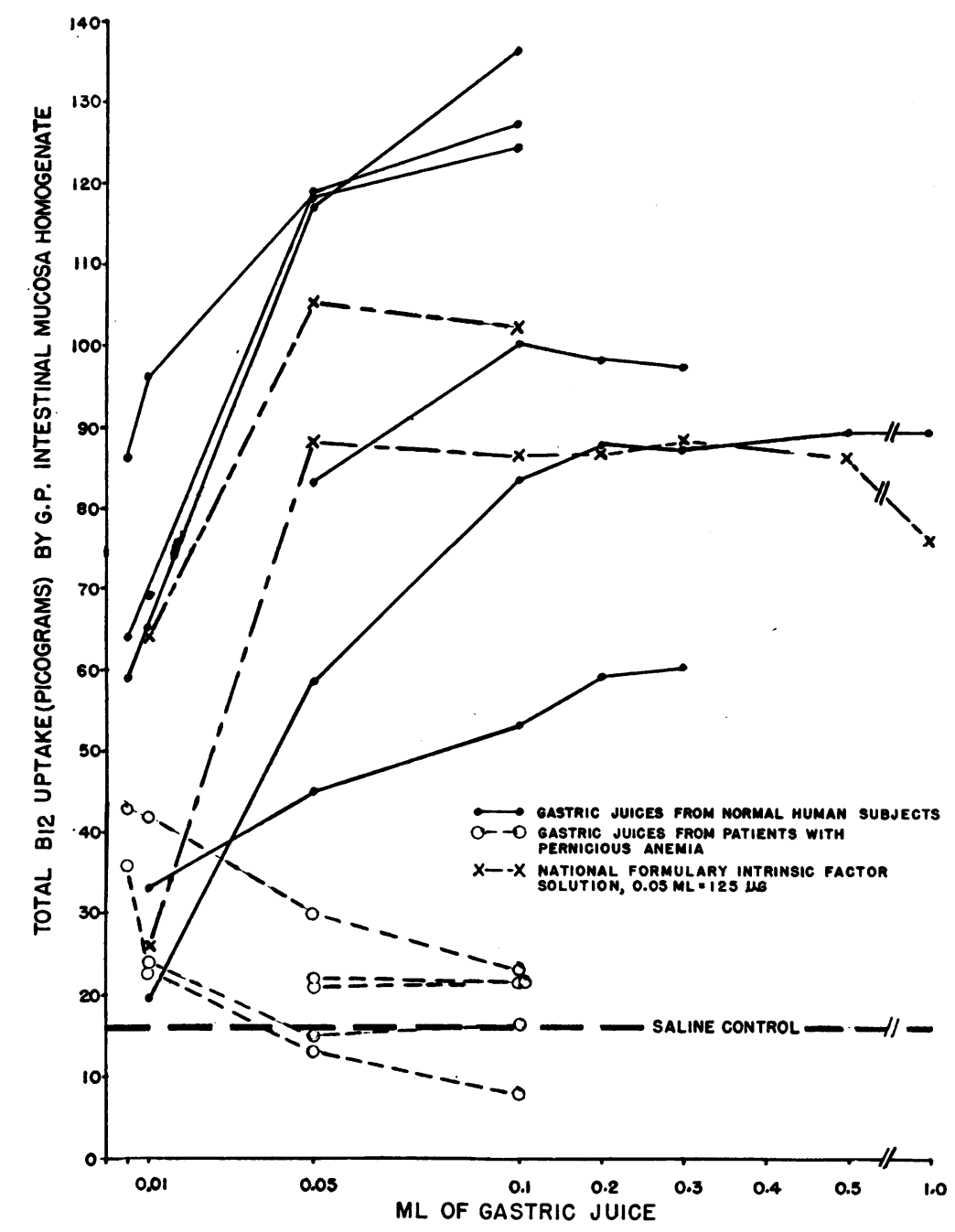

Fig. 1. EFFECT OF VARIOUS CONCENTRATIONS OF INTRINSIC FaCtor ON UPTAKe of $\mathrm{Co}^{57} \mathrm{~B}_{12}$ BY GUINEA-PIG INTESTINAL MUCOSA HoMogenATE.

TABLE II

Binding capacity, determined by dialysis, of NFIF for varying concentrations of $\mathrm{Co}^{57} B_{12}$

\begin{tabular}{|c|c|c|}
\hline Outer solution & $\begin{array}{l}\text { Inner } \\
\text { solution }\end{array}$ & $\begin{array}{c}\text { Percentage } \\
\text { of Co Co } \mathrm{B}_{12} \\
\text { bound by } \\
125 \mu \mathrm{gg} \\
\text { NFIF }\end{array}$ \\
\hline & & $\%$ \\
\hline 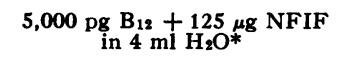 & $4 \mathrm{ml} \mathrm{H}_{2} \mathrm{O}^{*}$ & 88 \\
\hline $\begin{array}{c}10,000 \underset{\text { pg }}{B_{12}}+125 \mu \mathrm{g} \mathrm{NFIF} \\
\text { in } 4 \mathrm{ml} \mathrm{H}_{2} \mathrm{H}^{*}\end{array}$ & $4 \mathrm{ml} \mathrm{H}_{2} \mathrm{O}^{*}$ & 68 \\
\hline $\begin{array}{c}20,000 \underset{\text { in }}{\operatorname{pg}} \mathrm{B}_{12}+125 \mu \mathrm{ml} \mathrm{H}_{2} \mathrm{O}^{*} \\
\mathrm{~g} \text { NFIF }\end{array}$ & $4 \mathrm{ml} \mathrm{H}_{2} \mathrm{O} *$ & 36 \\
\hline 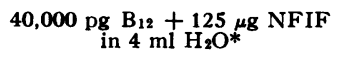 & $4 \mathrm{ml} \mathrm{H}{ }_{2} \mathrm{O}^{*}$ & 18 \\
\hline
\end{tabular}

* Deionized water.
It was further observed (Figure 1) that several gastric juices from patients with pernicious anemia gave greater uptake of vitamin $\mathrm{B}_{12}$ at concentrations of $0.005 \mathrm{ml}$ to $0.05 \mathrm{ml}$ than at $0.1 \mathrm{ml}$. This "paradoxical curve" has been observed in 8 out of 20 specimens of gastric juice from pernicious anemia patients assayed in serial concentrations, including basal and histamine-stimulated specimens, and may suggest the presence of an intrinsic factor inhibitor that can be removed by dilution.

Gastric juice from one patient with pernicious anemia resulted in less $B_{12}$ uptake than that of the saline control, perhaps owing to the presence of nonintrinsic factor $\mathrm{B}_{12}$ binders (or, alterna- 
tively, owing to the presence of nonfunctional intrinsic factor binding $\mathrm{B}_{12}$, or intrinsic factor inhibitors).

Determination of $B_{12}$-binding capacity. The $\mathrm{B}_{12}$-binding capacity of $125 \mu \mathrm{g}(0.05 \mathrm{ml}) \mathrm{NFIF}$ was determined by dialysis with Visking casing, as previously described (35). Of 5,000 pg $\mathrm{B}_{12}$ added (Table II), $88 \%$ was bound by $125 \mu \mathrm{g}$ of NFIF, indicating a binding capacity of approximately $35 \mathrm{pg} \mathrm{B}_{12}$ per $\mu \mathrm{g}$ IF. This is 0.1 the binding capacity previously found (35) for Lederle preparation Wes 671-A (323 pg $\mathrm{B}_{12}$ per $\mu \mathrm{g}$ IF), and is an example of correlation of binding capacity and clinical potency, since NFIF is clinically 0.1 as potent ( $50 \mathrm{mg}=1 \mathrm{USP}$ unit) as Wes 671-A ( $5 \mathrm{mg}=1 \mathrm{USP}$ unit) (16). As will be demonstrated below, such a correlation does not uniformly occur (Table X) (36).

Effect of varying concentrations of $\mathrm{Co}^{57} B_{12}$. Various amounts of $\mathrm{Co}^{57} \mathrm{~B}_{12}$ from 78 to 5,000 pg were added to the standard assay system. Figure 2 shows that with concentrations of 1,250 to $5,000 \mathrm{pg}$ per flask in the presence of intrinsic factor, the uptake of $\mathrm{B}_{12}$ by the homogenate is a

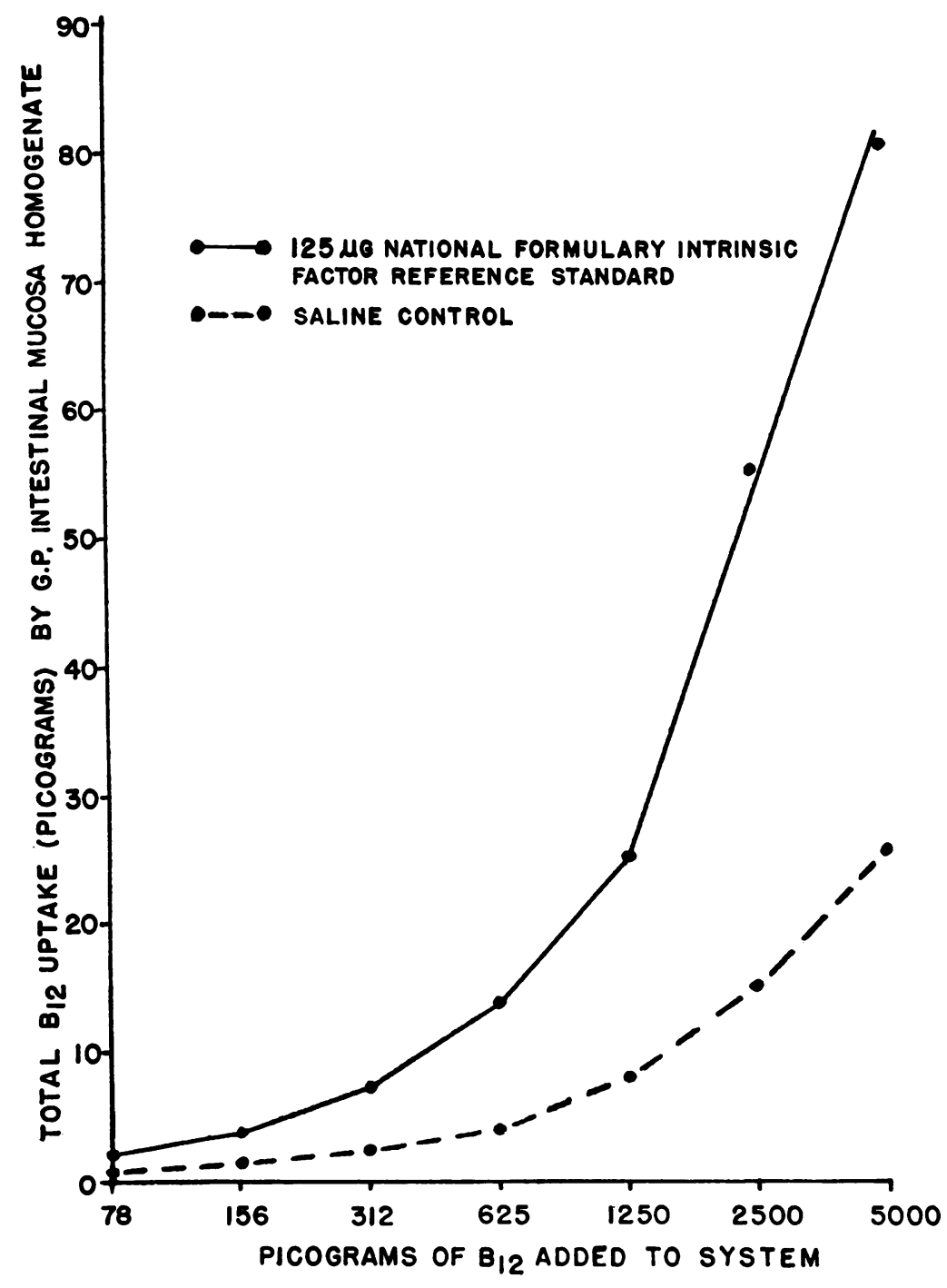

Fig. 2. Effect of various concentrations of $\mathrm{Co}^{57} \mathrm{~B}_{12}$, UP to 5,000 picoGRAMS, ON vitaMin $B_{12}$ UPTAKE BY GUINEA-PIG INTESTINAL MUCOSA HoMOGENATE. Note that abscissa scale is not arithmetic. 
TABLE III

Effect of glucose, hyperoxia, anoxia, and 2,4-dinitrophenol on standard guinea-pig intestinal mucosa homogenate assay

\begin{tabular}{|c|c|c|}
\hline Incubation medium & Specimen & $\begin{array}{l}\text { B }_{12} \text { Uptake } \\
\text { by homog- } \\
\text { enate }\end{array}$ \\
\hline Experiment A & & $p g$ \\
\hline Standard & Saline control & 78 \\
\hline Standard & NFIF & 154 \\
\hline$\underset{\text { glucose }}{\text { Standard }}+200 \mathrm{mg} / 100 \mathrm{ml}$ & NFIF & 156 \\
\hline \multicolumn{3}{|l|}{ Experiment $B$} \\
\hline $\begin{array}{l}\text { Standard; gaseous } \\
\text { phase-air }\end{array}$ & Saline control & 57 \\
\hline $\begin{array}{l}\text { Standard; gaseous } \\
\text { phase-air }\end{array}$ & NFIF & 192 \\
\hline $\begin{array}{l}\text { Standard; gaseous } \\
\text { phase- } 95 \% \mathrm{O}_{2}-5 \% \mathrm{CO}_{2}\end{array}$ & NFIF & 202 \\
\hline $\begin{array}{l}\text { Standard; gaseous } \\
\text { phase }-100 \% \mathrm{~N}_{2}\end{array}$ & NFIF & 197 \\
\hline \multicolumn{3}{|l|}{ Experiment C } \\
\hline Standard & Saline control & 21 \\
\hline Standard & NFIF & 112 \\
\hline Standard $+2,4-\mathrm{DN}_{\phi} *$ & NFIF & 102 \\
\hline Standard & NHGJ† & 97 \\
\hline Standard $+2,4-\mathrm{DN} \phi$ & NHGJ & 93 \\
\hline
\end{tabular}

*2,4-DN $\phi=2,4$-dinitrophenol, $10^{-4} \mathrm{M}$

$\dagger \mathrm{NHGJ}=$ Normal human gastric juice, $0.1 \mathrm{ml}$ direct function of the amount of $\mathrm{B}_{12}$ added. The ratio of the intrinsic factor curve to the control curve is approximately the same $(3.1$ to 4.0$)$ at these concentrations. With higher $\mathrm{B}_{12}$ concentrations $(7,500$ and $10,000 \mathrm{pg}$ per flask $)$, the curve ceased to be linear (Figure 3 ). Because $5,000 \mathrm{pg}$ gave the largest $B_{12}$ uptake without loss of linearity, this amount was chosen for the assay system.

Effect of glucose, hyperoxia, anoxia, and 2,4dinitrophenol. Table III summarizes three experiments suggesting that glucose (200 $\mathrm{mg}$ per $100 \mathrm{ml}$ ), hyperoxia, anoxia, and 2,4-dinitrophenol $\left(10^{-4} \mathrm{M}\right)$ do not affect $B_{12}$ uptake by the assay system.

Rate of uptake of $B_{12}$ by homogenate. To determine the rate of uptake of $\mathrm{B}_{12}$ by the homogenate, two series of duplicate tubes containing 0.1 $\mathrm{ml}$ and $0.2 \mathrm{ml}$ normal human gastric juice and a third series of saline controls were incubated at room temperature for periods of from 5 minutes to 4 hours. At the end of the incubation periods, the homogenate was immediately precipitated at $2,000 \times g$ in the cold and washed twice, and its radioactivity was determined (Figure 4 ). The

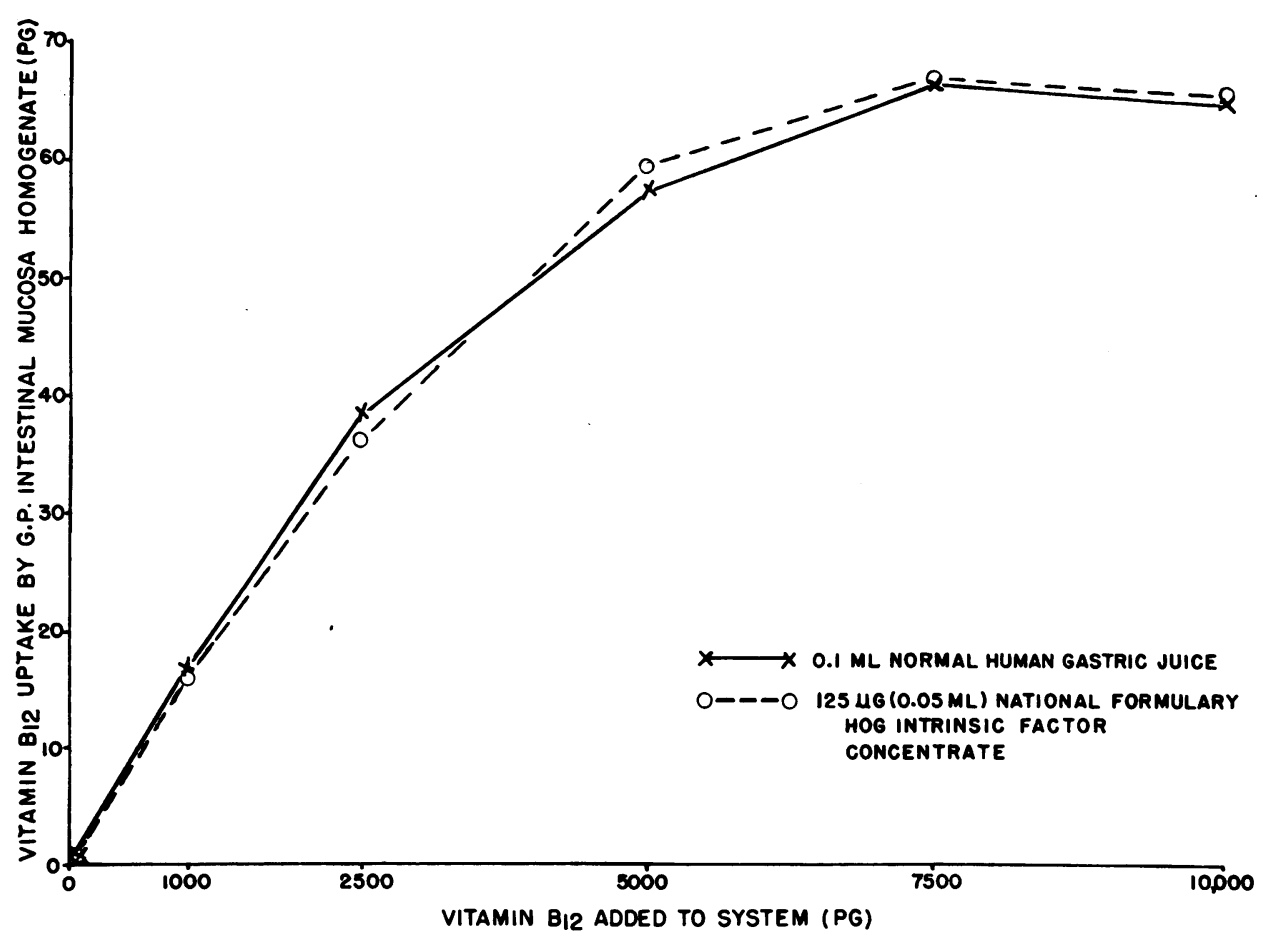

Fig. 3. EFFect of varying concentrations of $\mathrm{Co}^{57} \mathrm{~B}_{12}$, UP to 10,000 PiCograms, on vitamin $\mathrm{B}_{12}$ uptake by guinea-Pig intestinal mucosa homogenate. Abscissa scale is arithmetic. 


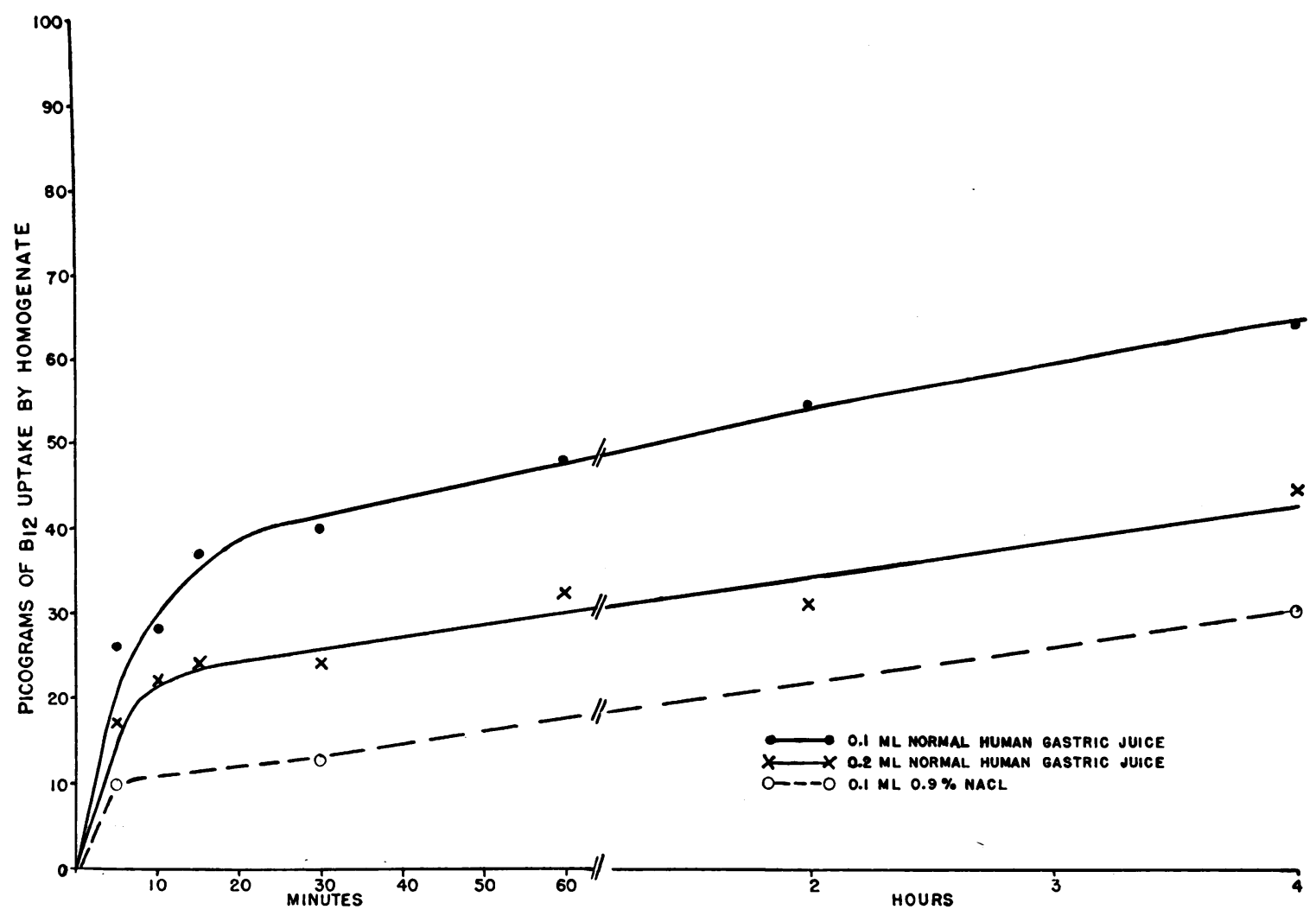

Fig. 4. Rate of uptake of vitamin $B_{12}$ in standard guinea-Pig intestinal mucosa homogénate assay.

rate of $\mathrm{B}_{12}$ uptake was noted to be most rapid in intrinsic factor. The curve for $0.2 \mathrm{ml}$ gastric the first 15 minutes and resembled a first-order juice was parallel to the curve for $0.1 \mathrm{ml}$, but the reaction. From 30 minutes to 4 hours, the up- quantitative $B_{12}$ uptake was less, suggesting that take was linear, at a much slower rate, and judged excess intrinsic factor was present, consistent with by the control rise, possibly not dependent upon the results of earlier experiments summarized in

TABLE IV

Effect of temperature on standard guinea-pig intestinal mucosa homogenate assay

\begin{tabular}{cccc}
\hline \hline Temperature & Sample & $\begin{array}{c}\mathrm{B}_{12} \text { Uptake by } \\
\text { homogenate }\end{array}$ & $\begin{array}{c}\mathrm{B}_{12} \text { Uptake or sample } \\
\overline{\mathrm{B}_{12} \text { uptake of control }}\end{array}$ \\
\hline Experiment D & & $p g$ & \\
$3^{\circ} \mathrm{C}$ & Saline control & 11 & 1.0 \\
$3^{\circ} \mathrm{C}$ & NHGJ & 137 & 6.1 \\
$3^{\circ} \mathrm{C}$ & NFIF & 66 & 1.0 \\
$25^{\circ} \mathrm{C}$ & Saline control & 18 & 9.5 \\
$25^{\circ} \mathrm{C}$ & NHGJ & 168 & \\
$25^{\circ} \mathrm{C}$ & NFIF & 135 & \\
& & & 1.0 \\
Experiment E & & 14 & 6.3 \\
$25^{\circ} \mathrm{C}$ & Saline control & 8.1 \\
$25^{\circ} \mathrm{C}$ & NHGJ & 88 & 1.0 \\
$25^{\circ} \mathrm{C}$ & NFIF & 85 & 6.8 \\
$37^{\circ} \mathrm{C}$ & Saline control & 139 & 5.6 \\
$37^{\circ} \mathrm{C}$ & NHGJ & 114 & \\
$37^{\circ} \mathrm{C}$ & NFIF & & \\
\hline
\end{tabular}


TABLE V

Effect of $p H$ on standard guinea-pig intestinal mucosa homogenate assay

\begin{tabular}{|c|c|c|c|}
\hline \multirow{2}{*}{$\begin{array}{c}\text { Buffered } \\
\text { medium, pH }\end{array}$} & \multicolumn{3}{|c|}{ B $_{12}$ Uptake by homogenate } \\
\hline & Saline & NHGJ & NFIF \\
\hline Experiment $\mathbf{F}$ & $p g$ & $p g$ & $p g$ \\
\hline $\begin{array}{l}5.4 \\
5.8 \\
6.2 \\
6.6 \\
7.2 \\
7.7\end{array}$ & $\begin{array}{l}4.9 \\
4.6 \\
4.5 \\
4.4 \\
6.0 \\
7.5\end{array}$ & $\begin{array}{r}4.9 \\
4.6 \\
15.4 \\
38.0 \\
36.6 \\
37.4\end{array}$ & $\begin{array}{r}2.0 \\
3.0 \\
16.9 \\
42.0 \\
40.0 \\
39.2\end{array}$ \\
\hline
\end{tabular}

Figure 1. The $\mathrm{B}_{12}$ uptake by the saline control flask also increased with time, so that by the end of 4 hours, the ratio of sample uptake to control uptake was less than at 30 minutes (2.1 vs. 2.5 ). For these reasons, 30 minutes was chosen as the usual incubation time.

Effect of temperature on uptake of $B_{12}$ by homogenate. Two experiments to determine the effect of various temperatures on uptake of $\mathrm{B}_{12}$ are summarized in Table IV. As the temperature was increased, the uptake of $\mathrm{B}_{12}$ was increased in all samples, including the saline control. As a result, there was no consistent or significant change in the $B_{12}$ uptake of sample: $B_{12}$ uptake of control ratio with increasing temperature.

$\mathrm{pH}$ dependence of system. At $\mathrm{pH} 5.4$ to 5.8, there is no enhancement of $B_{12}$ uptake by intrinsic factor; enhancement is evident at $\mathrm{pH} 6.2$, and is much greater at $\mathrm{pH} 6.6$ to 7.7 (Table V).
Effect of incubation of gastric juice at $p H 1.5$ before assay. Incubation of normal human gastric juice (with or without intact peptic activity) at $\mathrm{pH}$ 1.5 and $37^{\circ} \mathrm{C}$ for 18 hours before assay destroys its ability to enhance $B_{12}$ uptake by the homogenate (experiment $\mathrm{G}$ in Table VI). A sample of the same gastric juice neutralized to $\mathrm{pH} 7.0$, not previously incubated at $37^{\circ} \mathrm{C}$, enhanced $\mathrm{B}_{12}$ uptake seven times.

Effect of exposure to alkali. Normal human gastric juice was brought at room temperature to $\mathrm{pH} 11$ for 20 minutes to destroy its peptic activity. Thereafter, the specimen was backtitrated to $\mathrm{pH} 7$. The activity of the specimen was then compared to the activity of a sample of the same gastric juice that had been directly titrated to $\mathrm{pH} 7$ immediately after collection. As shown in experiment $\mathrm{H}$, no difference in the ability of the specimens to enhance $B_{12}$ uptake by the homogenate was demonstrated.

Effect of heating gastric juice. Experiment $\mathrm{J}$ (Table VII) shows that heating normal human gastric juice to $100^{\circ} \mathrm{C}$ for 5 minutes almost completely destroys its activity in the system. The hog intrinsic factor reference standard was similarly affected, to a lesser extent.

Effect of heating intestinal homogenate. Heating the intestinal homogenate to $100^{\circ} \mathrm{C}$ for 3 minutes destroys its intrinsic factor receptors, as shown by experiment $J$. In the presence of normal human gastric juice or hog intrinsic factor concentrate, the radioactive $B_{12}$ uptake by the

TABLE VI

Effect of prior incubation of normal human gastric juice at $p H 1.5$ and $p H 11$ on standard guinea-pig intestinal mucosa homogenate assay

\begin{tabular}{|c|c|c|}
\hline Sample & $\begin{array}{l}\mathrm{B}_{12} \text { Uptake by } \\
\text { homogenate }\end{array}$ & $\frac{B_{12} \text { Uptake of sample }}{B_{12} \text { uptake of control }}$ \\
\hline Experiment $\mathrm{G}$ & $p g$ & \\
\hline $\begin{array}{l}\text { NHGJ, }{ }^{*} \text { no. } 27 \\
\text { NHGJ, } \dagger \text { no. } 27, \text { acid-incubated } \\
\text { Saline control }\end{array}$ & $\begin{array}{r}112 \\
17 \\
16\end{array}$ & $\begin{array}{l}7.2 \\
1.1 \\
1.0\end{array}$ \\
\hline Experiment $\mathrm{H}$ & & \\
\hline $\begin{array}{l}\text { NHGJ, }{ }^{*} \text { no. } 22 \\
\text { NHGJ, } \ddagger \text { no. } 22 \text {, alkali-incubated } \\
\text { Saline control }\end{array}$ & $\begin{array}{r}104 \\
104 \\
40\end{array}$ & $\begin{array}{l}2.6 \\
2.6 \\
1.0\end{array}$ \\
\hline
\end{tabular}

* NHGJ-0.1 ml normal human gastric juice neutralized immediately after collection.

$\dagger$ Acid-incubated NHGJ-0.1 ml normal human gastric juice, incubated at $\mathrm{pH} 1.5$ for 18 hours immediately after collection and before neutralization.

$\ddagger$ Alkali-incubated NHGJ-normal human gastric juice titrated to $\mathrm{pH} 11$ immediately after collection for 20 minutes, then neutralized. 
heated homogenate is even lower than that of the saline control. This probably is the result of $\mathrm{B}_{12}$ binding by intrinsic factor, preventing passive diffusion of $\mathrm{B}_{12}$ into the homogenate. Heated human gastric juice or hog intrinsic factor concentrate gives values equal to those of the saline control.

Efficacy of acetone-zwashed lyophilized homogenate. Experiment $\mathrm{K}$ in Table VIII shows the comparative activities of lyophilized homogenate and of fresh homogenate. For comparison purposes, a single batch of homogenate was prepared, half of it being subsequently lyophilized. Equivalent amounts of fresh and lyophilized homogenate were run in separate flasks in an assay of a specimen of normal human gastric juice and the hog intrinsic factor reference standard. The results indicate that lyophilization does not destroy intrinsic factor receptors in the homogenate and that results are similar with either fresh or lyophilized material. The lyophilized material has retained sufficient activity after being stored at room temperature for 6 months to be useful in the assay system (experiment L).

Effect of storing fresh intestinal homogenate at
TABLE VII

Effect of prior heating on intrinsic factor and on intestinal homogenate in standard assay

\begin{tabular}{|c|c|c|}
\hline \multirow[b]{2}{*}{ Sample } & \multirow{2}{*}{$\begin{array}{l}\mathrm{B}_{12} \text { Uptake by } \\
\text { homogenate }\end{array}$} & \multirow{2}{*}{$\frac{B_{12} \text { Uptake of sample }}{B_{12} \text { uptake of control }}$} \\
\hline & & \\
\hline \multicolumn{3}{|l|}{ Experiment $\mathrm{J}$} \\
\hline \multicolumn{3}{|c|}{ Unheated homogenate } \\
\hline NHGJ & 112 & 5.5 \\
\hline NHGJ, heated* & 26 & 1.3 \\
\hline NFIF & 132 & 6.5 \\
\hline NFIF, heated* & 55 & 2.7 \\
\hline Saline control & 20 & 1.0 \\
\hline \multicolumn{3}{|l|}{ Heated homogenate* } \\
\hline NHGJ & 8 & 0.6 \\
\hline NHGJ, heated* & 15 & 1.2 \\
\hline NFIF & 7 & 0.6 \\
\hline NFIF, heated* & 11 & 0.9 \\
\hline Saline control & 12 & 1.0 \\
\hline
\end{tabular}

* Heated to $100^{\circ} \mathrm{C}$ for 5 minutes before assay.

$-20^{\circ} \mathrm{C}$. Fresh homogenate stored at $-20^{\circ} \mathrm{C}$ for $8 \frac{1}{2}$ months has intact intrinsic factor receptors as demonstrated in experiment $\mathrm{M}$.

Efficacy of lyophilized mixture of homogenate, $K R T$ buffer, and $C_{0^{57}} B_{12}$. Attempts to prepare a consistently reliable "dry mix" of homogenate, buffer, and radioactive $B_{12}$ in a single lyophilized

TABLE VIII

Efficacy of various fresh and lyophilized guinea-pig intestinal homogenate preparations

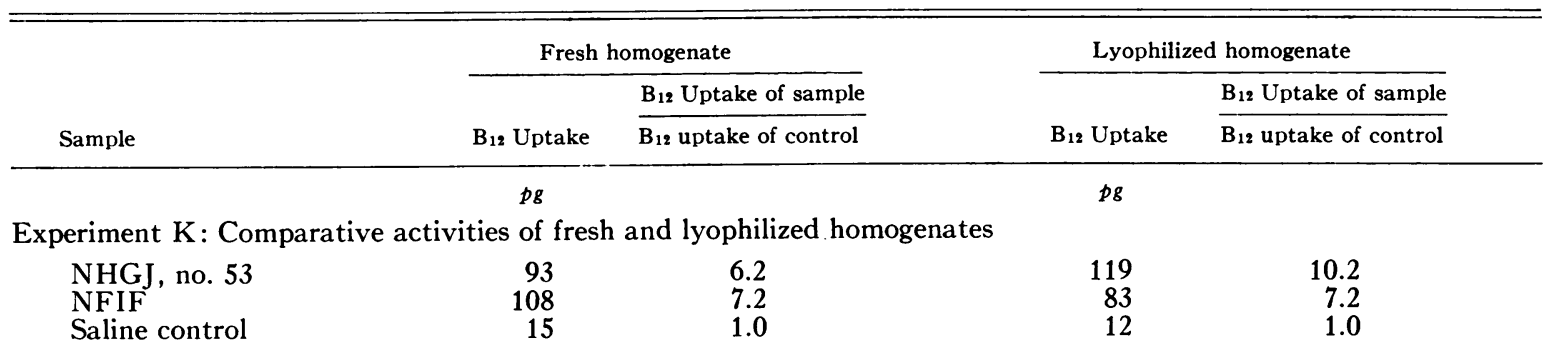

Experiment L: Activity of lyophilized homogenate stored at room temperature for 6 months

$\begin{array}{lcc}\text { NHGJ, no. } 53 & 81 & 3.9 \\ \text { NHGJ, no. } 60 & 66 & 3.2 \\ \text { Saline control } & 21 & 1.0\end{array}$

Experiment M : Activity of fresh intestinal homogenate stored for $8 \frac{1}{2}$ months at $-20^{\circ} \mathrm{C}$

$\begin{array}{lll}\text { NHGJ, no. } 53 & 95 & 5.1 \\ \text { NFIF } & 65 & 3.5 \\ \text { Saline control } & 19 & 1.0\end{array}$

Experiment N: Activity of lyophilized mixture of intestinal homogenate, Krebs-Ringer-Tris buffer and $\mathrm{Co}^{57} \mathrm{~B}_{12}$ as an assay substrate for intrinsic factor

NHGJ, no. 53

PAGJ*

NFIF

Saline control

$\begin{array}{rr}34 & 2.6 \\ 7 & 0.5 \\ 19 & 1.4 \\ 13 & 1.0\end{array}$

* PAGJ = gastric juice from a patient with pernicious anemia. 
TABLE IX

Effect of intrinsic factor antibodies on standard guinea-pig intestinal mucosa homogenate assay

\begin{tabular}{lcc}
\hline \multicolumn{1}{c}{ Sample } & $\begin{array}{c}\text { B }_{12} \text { Uptake by } \\
\text { homogenate }\end{array}$ & $\begin{array}{c}\text { B }_{12} \text { Uptake of sample } \\
\text { B }_{12} \text { uptake of control }\end{array}$ \\
\hline Experiment O & $p g$ & \\
NHGJ & 58 & 5.4 \\
NHGJ + normal rabbit serum* & 62 & 5.6 \\
NHGJ + rabbit antihuman intrinsic factor $\dagger$ & 15 & 1.3 \\
Saline control & 11 & 1.0 \\
Experiment P & & \\
NFIF & 60 & 4.0 \\
NFIF + rabbit antihuman intrinsic factor $\ddagger$ & 12 & 0.8 \\
NHGJ + rabbit antihog intrinsic factor & 26 & 1.7 \\
NHGJ & 11 & 0.7 \\
Saline control & 15 & 1.0 \\
\hline
\end{tabular}

* Normal rabbit serum, $0.2 \mathrm{ml}$.

† Rabbit antihuman stomach mucosa serum, $0.2 \mathrm{ml}$.

$\ddagger$ Rabbit antihuman stomach mucosa serum, $0.1 \mathrm{ml}$.

\&abbit antihog serum, $0.1 \mathrm{ml}$.

substance have been only partially successful. This may be due to osmotic damage to the intrinsic factor receptors occurring during lyophilization with KRT buffer. Experiment $\mathrm{N}$ represents an assay in which this "dry mix" was used.
Although there is enhancement of $B_{12}$ uptake by the "dry-mix" homogenate with normal gastric juice and hog intrinsic factor concentrate, the uptake was only $\frac{1}{5}$ to $\frac{1}{3}$ of that obtained with fresh or lyophilized homogenate (experiment $\mathrm{K}$ )

TABLE $\mathbf{X}$

Correlation of standard guinea-pig intestinal mucosa homogenate assay with modified Schilling test; lack of correlation between intrinsic factor activity and $B_{12}$-binding capacity of human gastric juice

\begin{tabular}{|c|c|c|c|}
\hline Human gastric juice & $\begin{array}{l}\text { Schilling test : } \\
\% \text { dose } \\
\text { excreted }\end{array}$ & $\begin{array}{l}\text { Homogenate assay: } \\
\text { B } 12 \text { Uptake of sample } \\
\mathrm{B}_{12} \text { uptake of control }\end{array}$ & $\begin{array}{c}\text { Percentage of } \\
5,000 \mathrm{pg} \mathrm{B}_{12} \\
\text { bound by } 0.1 \mathrm{ml} \\
\text { gastric juice* }\end{array}$ \\
\hline \multicolumn{4}{|l|}{ Normal $30 \mathrm{ml}$} \\
\hline $\begin{array}{l}20 \\
24 \\
21 \\
25 \\
22 \\
23\end{array}$ & $\begin{array}{r}4.5 \\
10.9 \\
7.7 \\
6.0 \\
5.1 \\
7.6\end{array}$ & $\begin{array}{l}2.7 \\
2.8 \\
3.3 \\
3.5 \\
3.6 \\
3.6\end{array}$ & $\begin{array}{l}11.4 \\
41.2 \\
17.7 \\
\\
15.4\end{array}$ \\
\hline \multicolumn{4}{|c|}{ Nonpernicious anemia } \\
\hline $\begin{array}{l}50 \dagger \\
63 \ddagger \\
53 \S\end{array}$ & $\begin{array}{r}6.7 \\
16.9 \\
22.8\end{array}$ & $\begin{array}{l}2.3 \\
3.9 \\
6.8\end{array}$ & 16.9 \\
\hline \multicolumn{4}{|l|}{ Pernicious anemia } \\
\hline $\begin{array}{l}39 \\
48 \\
66 \\
35 \mathrm{a} \| \\
35 \mathrm{~b} \| \\
31\end{array}$ & $\begin{array}{l}1.5 \\
0.9 \\
1.5 \\
0.9 \\
1.3 \\
4.2\end{array}$ & $\begin{array}{l}1.1 \\
1.5 \\
1.2 \\
0.3 \\
0.8 \\
3.5\end{array}$ & 41.4 \\
\hline
\end{tabular}

* Binding capacity determined by dialysis as indicated in reference 35 .

t Combined $B_{12}$ and folic acid deficiency, 4 weeks postpartum.

$¥$ Folic acid deficiency.

\& Dietary $\mathrm{B}_{12}$ deficiency.

Specimens from the same patient, 12 days apart. 


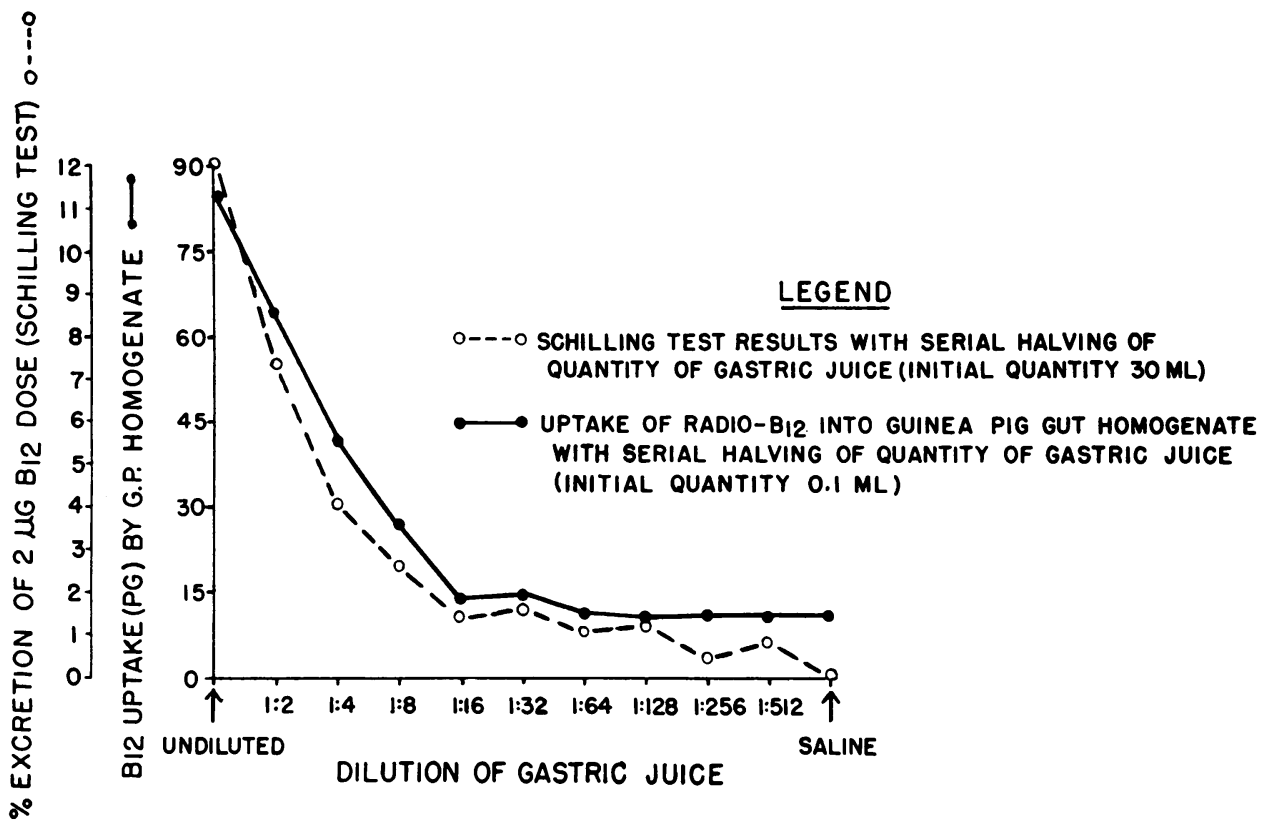

Fig. 5. Correlation of in vitro standard guinea-pig intestinal mucosa homogenate ASSAY WITH in vivo ASSAY (SCHILLING TEST) FOR INTRINSIC FACTOR ACTIVITY IN SERIAL DILUTIONS OF NORMAL HUMAN GASTRIC JUICE.

using the same gastric juice and hog intrinsic factor concentrate. However, our studies suggest that adding lyophilized KRT and radioactive $\mathrm{B}_{12}$ to lyophilized homogenate may result in a "dry mix" without significant loss of receptors.

Effect of intrinsic factor antisera on in vitro assay. Potent rabbit antisera to hog intrinsic factor concentrate (37) and to human stomach mucosa ${ }^{3}$ inhibited the $B_{12}$ uptake mediated by hog intrinsic factor concentrate and by human gastric juice (Table IX). Cross-reactivity with heterologous antigen was exhibited by both antisera (Table IX).

Correlation of assay with clinical activity of gastric juices. To test the assay system for physiologic relevance, gastric juices from normal individuals and from patients with megaloblastic anemias of various etiologies were collected and assayed. This in vitro activity was then compared with in vivo activity, i.e., the alsility of $30 \mathrm{ml}$ of the unknown gastric juice to promote absorption of a 2- $\mu \mathrm{g}$ dose of $\mathrm{Co}^{60} \mathrm{~B}_{12}$ in a Schilling-type test (31) performed on a group of patients with pernicious anemia. Table $\mathrm{X}$ demonstrates that all specimens from normal individuals and from pa-

\footnotetext{
${ }^{3}$ Prepared and supplied by Dr. Manuel Kaplan.
}

tients with megaloblastic anemia owing to dietary deficiencies of $\mathrm{B}_{12}$ or folic acid produced a twofold or greater enhancement of $\mathrm{B}_{12}$ uptake by the homogenate. These gastric juices gave normal Schilling test results when fed to pernicious anemia patients, indicating normal intrinsic factor activity.

Of six gastric juice specimens from patients with documented pernicious anemia, five showed insignificant in vitro and in vivo activity (Table $\mathrm{X})$. The sixth pernicious anemia patient is of interest in that his gastric juice produced an enhancement of $\mathrm{B}_{12}$ uptake by the homogenate of $3 \frac{1}{2}$ times. With 4 hours of continuous nasogastric suction, a total of $25 \mathrm{ml}$ of viscous gastric juice with a $\mathrm{pH}$ of 8.0 was obtained. When fed with $2 \mu \mathrm{g}$ of $\mathrm{Co}^{60} \mathrm{~B}_{12}$ to another patient with pernicious anemia, $4.2 \%$ of the administered radioactivity was excreted in the urine, suggesting the presence of significant amounts of intrinsic factor, as indicated by the in vitro assay.

No correlation was found between the $\mathrm{B}_{12^{-}}$ binding activity of gastric juice, as determined by dialysis, and the in vivo or in vitro intrinsic factor activity of gastric juice (Table X). Indeed, the gastric juice which had the greatest $\mathrm{B}_{12}$-binding 
capacity was from a patient with pernicious anemia and was without activity in the in vivo or in vitro assays.

The correlation between the in vivo and in vitro assays was studied further by making serial dilutions of a sample of normal human gastric juice with $0.9 \%$ saline. Thirty-ml samples of each dilution of gastric juice were serially fed with 2 $\mu \mathrm{g}$ of $\mathrm{Co}^{60} \mathrm{~B}_{12}$ in Schilling-type tests (31) to a single patient with pernicious anemia in remission. The intrinsic factor activity of the dilutions of gastric juice was compared with the ability of $0.1 \mathrm{ml}$ of each dilution to enhance radioactive $B_{12}$ uptake in the standard guinea-pig gut homogenate assay. The results are plotted in Figure 5. In both in vivo and in vitro assays, the gastric juice showed parallel intrinsic factor activity. In 1:16 dilution and beyond, there was no significant intrinsic factor activity demonstrable by either assay, the in vivo assay resulting in less than $2 \%$ excretion of the radioactive $B_{12}$ dose, and the in vitro assay showing uptake of radioactive $B_{12}$ no greater than that of the saline control.

Effect of histamine on intrinsic factor secretion. Comparisons of intrinsic factor activity of gastric juice obtained under basal conditions with that of gastric juice obtained after maximal histamine stimulation are shown in Table XI. After histamine stimulation, in three of five normal subjects, the intrinsic factor activity per unit volume of gastric juice increased by factors of 1.6, 4.7, and 23.5 , respectively, and there was also a two- to fivefold increase in volume of gastric secretion during the 45-minute collection periods. In Subject 22 , the volume of secretion obtained after histamine stimulation was less than the basal volume, but the total secretion of intrinsic factor was unchanged because of the greater intrinsic factor activity per $0.1 \mathrm{ml}$ of the posthistamine gastric

TABLE XI

Comparison of in vitro intrinsic factor activities of human gastric juice obtained before and after maximal histamine stimulation

\begin{tabular}{|c|c|c|c|c|c|c|}
\hline \multirow[b]{2}{*}{ Source of gastric juice } & \multicolumn{2}{|c|}{$\begin{array}{l}\text { Gastric juice } \\
\text { secreted in } 45 \\
\text { minutes }\end{array}$} & \multicolumn{2}{|c|}{$\begin{array}{c}\text { Amount of } B_{12} \\
\text { uptake facilitated } \\
\text { by } 0.1 \text { ml gastric } \\
\text { juice* }\end{array}$} & \multirow{2}{*}{$\begin{array}{l}\text { Ratio of } \\
\text { activity of } \\
\text { gastric } \\
\text { juice }\end{array}$} & \multirow{2}{*}{$\frac{\text { After histamine }}{\text { before histamine }}$} \\
\hline & $\begin{array}{c}\text { Before } \\
\text { histamine }\end{array}$ & $\begin{array}{c}\text { After } \\
\text { histamine }\end{array}$ & $\begin{array}{c}\text { Before } \\
\text { histamine }\end{array}$ & $\begin{array}{c}\text { After } \\
\text { histamine }\end{array}$ & & \\
\hline & $m l$ & $m l$ & $p g$ & $p g$ & $10.1 \mathrm{ml}$ & $\begin{array}{l}\text { /45-min } \\
\text { sample }\end{array}$ \\
\hline \multicolumn{7}{|l|}{ Normal subjects } \\
\hline $\begin{array}{l}20 \\
21 \\
22 \\
23 \\
24\end{array}$ & $\begin{array}{r}53 \\
40 \\
106 \\
83 \\
26\end{array}$ & $\begin{array}{r}123 \\
203 \\
68 \\
185 \\
132\end{array}$ & $\begin{array}{r}29 \\
15 \\
52 \\
51 \\
2\end{array}$ & $\begin{array}{l}48 \\
70 \\
78 \\
32 \\
47\end{array}$ & $\begin{array}{r}1.6 \\
4.7 \\
1.5 \\
0.6 \\
23.5\end{array}$ & $\begin{array}{r}3.7 \\
24.0 \\
1.0 \\
1.3 \\
120.0\end{array}$ \\
\hline \multicolumn{7}{|l|}{$\begin{array}{l}\text { Folic acid-deficient } \\
\text { patients }\end{array}$} \\
\hline $\begin{array}{l}60 \\
63\end{array}$ & $\begin{array}{l}22 \\
22\end{array}$ & $\begin{array}{l}98 \\
79\end{array}$ & $\begin{array}{l}65 \\
81\end{array}$ & $\stackrel{63}{0 \dagger}$ & 1.0 & 4.5 \\
\hline \multicolumn{7}{|l|}{$\begin{array}{c}\text { Dietary } B_{12} \text {-deficient } \\
\text { patient }\end{array}$} \\
\hline 53 & 90 & 285 & 40 & 56 & 1.4 & 4.4 \\
\hline \multicolumn{7}{|l|}{$\begin{array}{l}\text { Pernicious anemia } \\
\text { patients }\end{array}$} \\
\hline $\begin{array}{l}28 \\
35 \\
40 \\
41 \\
59\end{array}$ & $\begin{array}{r}3 \\
21 \\
30 \\
4 \\
4\end{array}$ & $\begin{array}{r}2 \\
45 \\
13 \\
6 \\
2\end{array}$ & $\begin{array}{r}-21 \\
-7 \\
-3 \\
-5 \\
3\end{array}$ & $\begin{array}{r}-6 \\
-17 \\
1 \\
0 \\
3\end{array}$ & $\begin{array}{l}0 \\
0 \\
1 \\
0 \\
1\end{array}$ & $\begin{array}{l}0 \\
0 \\
0.4 \\
0 \\
0.5\end{array}$ \\
\hline
\end{tabular}

* Values represent the picograms of $B_{12}$ taken up in excess of the uptake by the saline controls. A minus value means the amount of $\mathrm{B}_{12}$ uptake was less than that of the saline control.

$\dagger$ Histamine specimen moderately contaminated with blood. 
juice. Subject 23 had a lower intrinsic factor activity per $0.1 \mathrm{ml}$ gastric juice in the posthistamine specimen. Because of the greater volume of gastric juice, however, intrinsic factor secretion was greater in the posthistamine period. In one patient (no. 63) with folic acid deficiency, the posthistamine specimen contained a moderate amount of blood. This specimen was inactive in the in vitro system, possibly owing to blocking of intrinsic factor activity by blood group substance (38). None of the specimens from the patients with pernicious anemia showed significant intrinsic factor activity in the basal or posthistamine secretions, and several gave values less than the saline controls (indicated by the minus signs), suggesting the presence of nonintrinsic factor $B_{12}$ binders.

\section{DISCUSSION}

The general acceptance of any in vitro assay depends on the demonstration of its ability to give results consistent with physiologic fact. Additional desirable characteristics are simplicity and reproducibility. The present studies suggest that a guinea-pig intestinal mucosa homogenate assay for human (and hog) intrinsic factor meets these requirements. This system has reliably shown the presence or absence of intrinsic factor in all specimens of gastric juice tested (including those from patients with free acid), as confirmed by the ability of the gastric juice to promote absorption of radioactive $B_{12}$ in patients with pernicious anemia. All normal gastric juices gave a twofold or greater enhancement of vitamin $B_{12}$ uptake by the homogenate.

The finding of detectable intrinsic factor activity in the gastric juice of one patient with pernicious anemia confirms the studies of three decades ago $(2,39)$ indicating the presence of intrinsic factor in the gastric juice of some pernicious anemia patients. Inadequate intrinsic factor output per day can thus result from secretion of an inadequate volume of gastric juice containing a normal concentration of intrinsic factor, from secretion of a normal volume of gastric juice containing a reduced concentration of intrinsic factor, or from appropriate combinations of these circumstances. In vitro assays for human intrinsic factor activity will simplify long-term studies $(40,41)$ delineating the natural history of the decline in intrinsic factor as pernicious anemia develops.

It should be noted that both in ritro and in a'vio assays measure effective intrinsic factor activity and not necessarily total intrinsic factor content. The quantity of nonintrinsic factor $\mathrm{B}_{12}$ binders (and other inhibitors) may vary from one gastric juice to another. Both assays measure the net physiologic result of an unknown number of units of intrinsic factor plus an unknown number of inhibitors. The observation that at concentrations of 0.005 to $0.01 \mathrm{ml}$ of gastric juice from some pernicious anemia patients, there was slight enhancement of $\mathrm{B}_{12}$ uptake, which was not demonstrable at higher concentrations, suggests the possibility that an "inhibitor" of intrinsic factor may have been diluted out at the lower concentrations.

Since intrinsic factor has not yet been isolated in pure form, any in vitro assay may be suspect. Supporting the validity of the methodology here described as an assay for human intrinsic factor activity are the following observations: $a$ ) the material in human gastric juice which enhances radioactive $B_{12}$ uptake by guinea pig intestinal mucosa homogenate resembled human intrinsic factor in its destruction by heat (2) or prolonged exposure to acid before or after inactivation of pepsin (3), and in its resistance to moderate alkalinity (4) for a short period or storage for weeks at $-20^{\circ} \mathrm{C}$ at neutral $\mathrm{pH}(1) ; b$ ) intestinal homogenate will not serve as a source of "receptors" after heating or at $\mathrm{pH} 5.8$ or lower (5-7), suggesting that the system is not measuring a nonspecific binding effect;c) 4 samples of colostrum and 8 samples of saliva, substances known to have $\mathrm{B}_{12}$-binding properties, do not enhance $B_{12}$ uptake by the homogenate, and there was no relation between $\mathrm{B}_{12}$-binding power and assay potency of the various gastric juices; $d$ ) immunologic studies show that a potent rabbit antiserum to human stomach mucosa blocks the activity of human gastric juice and hog intrinsic factor concentrate in the homogenate system and that rabbit antihog intrinsic factor antibody inhibits the action of human gastric juice and hog intrinsic factor concentrate.

The assay system was not affected by anoxia, hyperoxia, glucose, or 2,4-dinitrophenol. With $5,000 \mathrm{pg}$ radioactive $\mathrm{B}_{12}$, increasing concentrations of normal gastric juice up to $0.1 \mathrm{ml}$ resulted 
in increased radioactive $B_{12}$ uptake by the homogenate. Beyond $0.1 \mathrm{ml}$, there was no significantly greater enhancement; with much larger quantities there was some inhibition of $\mathrm{B}_{12}$ uptake. This phenomenon suggests that with $0.1 \mathrm{ml}$ the "receptors" on the intestinal homogenate are nearly saturated $(16,17)$. The rate of uptake of radioactive $B_{12}$ by the homogenate was rapid during the first 15 to 30 minutes, but a continued, slower uptake was observed for as long as 4 hours, paralleled, however, by the saline control.

Guinea-pig intestinal mucosa homogenate "receptors" for intrinsic factor appear to remain essentially intact after lyophilization, acetone washing, and relyophilization. This makes possible the preparation of large quantities of lyophilized material to serve as a substrate that may be stored at room temperature and used as needed for repeated assays of human intrinsic factor. Vitamin $\mathrm{B}_{12}$ binding cannot be used as a measure of intrinsic factor activity in unfractionated human gastric juice. Of the gastric juices in which $\mathrm{B}_{12}$-binding capacity was measured, the one with greatest binding capacity had no in vivo or in vitro intrinsic factor activity. Many others have previously noted the lack of correlation between total $\mathrm{B}_{12}$-binding capacity of gastric juice and intrinsic factor activity $(36,42,43)$ and the fact that many materials other than intrinsic factor bind vitamin $\mathrm{B}_{12}$ (43).

The in vitro guinea-pig intestinal mucosa homogenate assay technique can be incorporated into routine gastric analysis, and results are available the same day. It requires no administration of radioactivity to the patient and no urine or stool collections or body surface scanning. It appears to be a more direct measure of intrinsic factor activity than in vivo assays measuring fecal, serum, liver, urine, or whole body radioactivity, since it is performed on the gastric juice itself.

Finally, it must again be emphasized that too much intrinsic factor will result in lowered vita$\min \mathrm{B}_{12}$ uptake by the homogenate because of the critical nature of the ratios vitamin $\mathrm{B}_{12}$ : intrinsic factor: receptors (7). The importance of this point is illustrated by the fact that others were unsuccessful (44) in attempts to confirm our initial indication (7) that guinea-pig gut homogenate could be used for intrinsic factor assay, until our suggestion (45) to use $0.02 \mathrm{ml}$ of human gastric juice was adopted (46). Subsequently, we reported (26) use of the ratio 0.1 ml gastric juice: 5,000 pg $B_{12}$ and, using that ratio, others confirmed that report in detail (47).

The finding that the intrinsic factor activity of gastric juice from six of eight subjects without pernicious anemia was greater in the posthistamine specimens suggests that, in addition to the enhancement of hydrochloric acid secretion and pepsin secretion (48-51), histamine stimulates intrinsic factor secretion. Since present evidence suggests that both pepsin (51) and intrinsic factor (52) are products of the chief cell, the increase in intrinsic factor secretion after histamine is not surprising. The possibility that the increased intrinsic factor activity represents a "washing-out" of intrinsic factor from the glandular crypts cannot at present be excluded.

\section{SUMMARY}

Homogenate of mucosa from the distal half of the guinea-pig small intestine appears to provide a simple, reliable, rapid in vitro assay for intrinsic factor, which correlates well with in vivo assays. The present study demonstrates this with both human and hog intrinsic factor.

The specificity of the system for intrinsic factor is further suggested by the findings that the activity of gastric juice in the homogenate system, like the activity of intrinsic factor, is reversibly inhibited at $\mathrm{pH} 5.8$ and below, and is destroyed by heat or prolonged exposure to acid, but not by moderately alkaline $\mathrm{pH}$ or by storage at $-20^{\circ} \mathrm{C}$ at neutral $\mathrm{pH}$. Antibody to human stomach mucosa inhibits the uptake of $\mathrm{B}_{12}$ mediated by human gastric juice. $\mathrm{B}_{12}$-binding proteins other than intrinsic factor do not enhance $B_{12}$ uptake by the homogenate.

The homogenate may be stored frozen, or lyophilized and stored at room temperature for use as needed. The assay may be incorporated into routine gastric analysis, requires less than $1.0 \mathrm{ml}$ of gastric juice, is a direct measure of intrinsic factor activity, and can provide results within an hour.

\section{ACKNOWLEDGMENT}

The authors are indebted to Mrs. Brenda Conti Dicken, Mrs. Nancy Cunneen Boardman, Mrs. Margaret Clifford, and Miss Virginia Chapin for technical assistance. 


\section{ADDENDUM}

Lyophilized homogenate has been shown to retain normal activity after storage for 16 months at room temperature. In further immunologic studies, we demonstrated that rabbit antihog intrinsic factor antibody completely destroys the activity of NFIF in the homogenate system. Maintenance of gastric juice at $\mathrm{pH} 7$ for 18 hours at $37^{\circ} \mathrm{C}$ did not significantly reduce its activity when pepsin had been previously inactivated.

\section{REFERENCES}

1. Castle, W. B. Observations of the etiologic relationship of achylia gastrica to pernicious anemia: I. The effect of the administration to patients with pernicious anemia of the contents of the normal human stomach recovered after the ingestion of beef muscle. Amer. J. med. Sci. 1929, 178, 748.

2. Castle, W. B., C. W. Heath, and M. B. Strauss. Observations on the etiologic relationship of achylia gastrica to pernicious anemia: IV. A biologic assay of the gastric secretion of patients with pernicious anemia having free hydrochloric acid and that of patients without anemia or with hypochromic anemia having no free hydrochloric acid, and the role of intestinal impermeability to hematopoietic substances in pernicious anemia. Amer. J. med. Sci. 1931, 182, 741.

3. Castle, W. B., and T. H. Ham. Observations on the etiologic relationship of achylia gastrica to pernicious anemia. V. Further evidence for the essential participation of intrinsic factor in hematopoietic responses to mixtures of beef muscle and gastric juice and to hog stomach mucosa. J. Amer. med. Ass. 1936, 107, 1456.

4. Flood, C., and R. West. Some properties of Castle's intrinsic factor. Proc. Soc. exp. Biol. (N. Y.) 1936, 35, 542.

5. Castle, W. B., C. W. Heath, M. B. Strauss, and R. W. Heinle. Observations on the etiologic relationship of achylia gastrica to pernicious anemia. VI. The site of the interaction of food (extrinsic) and gastric (intrinsic) factors; failure of in vitro incubation to produce a thermostable hematopoietic principle. Amer. J. med. Sci. 1937, 194, 618.

6. Veeger, W., J. Abels, N. Hellemans, and H. O. Nieweg. Effect of sodium bicarbonate and pancreatin on the absorption of vitamin $B_{12}$ and fat in pancreatic insufficiency. New Engl. J. Med. 1962, 267, 1341.

7. Herbert, V., and W. B. Castle. Divalent cation and $\mathrm{pH}$ dependence of rat intrinsic factor action in everted sacs and mucosal homogenates of rat small intestine. J. clin. Invest. 1961, 40, 1978.

8. Minot, G. R., and W. B. Castle. The interpretation of reticulocyte reactions, their value in determining the potency of therapeutic materials, especially in pernicious anemia. Lancet 1935, 2, 319.
9. Heinle, R. W., A. D. Welch, V. Scharf, G. C. Meacham, and W. H. Prusoff. Studies of excretion (and absorption) of $\mathrm{Co}^{\mathrm{on}}$-labeled vitamin $\mathrm{B}_{1:}$ in pernicious anemia. Trans. Ass. Amer. Phycns 1952, 65, 214.

10. Schilling, R. F. Intrinsic factor studies. II. The effect of gastric juice on the urinary excretion of radioactivity after the oral administration of radioactive vitamin $B_{12}$. J. Lab. clin. Med. 1953, 42, 860.

11. Glass, G. B. J., L. J. Boyd, G. A. Bellin, and L. Stephanson. Uptake of radioactive vitamin $B_{12}$ by the liver in humans : test of measurement of intestinal absorption of vitamin $B_{12}$ and intrinsic factor activity. Arch. Biochem. 1954, 51, 251.

12. Booth, C. C., and D. L. Mollin. Plasma, tissue and urinary radioactivity after oral administration of ${ }^{56} \mathrm{Co}$-labelled $\mathrm{B}_{12}$ in Vitamin $\mathrm{B}_{12}$ and Intrinsic Factor, H. C. Heinrich, Ed. Stuttgart, Ferdinand Enke, 1957, p. 431.

13. Reizenstein, P. A., E. P. Cronkite, and S. H. Cohn. Measurement of absorption of vitamin $\mathrm{B}_{12}$ by whole-body gamma spectrometry. Blood 1961, 18, 95.

14. Heinrich, H. C., and A. A. Pfau. Der Einsatz von Gersamtcörper-Radioactivitäts-Detektoren mit flussigen organischen Szintillatoren in der Klinischen Radioisotopen Diagnostik und Forschung. Atomkernenergie 1961, 6, 463.

15. Miller, O. N., and F. M. Hunter. Stimulation of vitamin $B_{12}$ uptake in tissue slices by intrinsic factor concentrate. Proc. Soc. exp. Biol. (N. Y.) 1957, 96, 39.

16. Herbert, V. Development of a possible in vitro assay for intrinsic factor. Proc. Soc. exp. Biol. (N. Y.) 1958, 97, 668.

17. Herbert, V. Studies on the role of intrinsic factor in vitamin $\mathrm{B}_{12}$ absorption, transport, and storage. Amer. J. clin. Nutr. 1959, 7, 433.

18. Minard, F. N., and C. L. Wagner. In vitro assay of hog intrinsic factor with rat liver homogenates. Proc. Soc. exp. Biol. (N. Y.) 1958, 98, 684.

19. Herbert, V. The Megaloblastic Anemias. New York, Grune \& Stratton, 1959.

20. Herbert, V., Z. Castro, and L. R. Wasserman. Stoichiometric relation between liver-receptor, intrinsic factor and vitamin $B_{12}$. Proc. Soc. exp. Biol. (N. Y.) $1960,104,160$.

21. Bromer, W. W., and E. O. Davidson. Preparation and characterization of a clinically effective porcine intrinsic factor-vitamin $\mathrm{B}_{12}$ complex in Vitamin $\mathrm{B}_{12}$ and Intrinsic Factor, H. C. Heinrich, Ed. Stuttgart, Ferdinand Enke, 1962, p. 457.

22. Wilson, T. H., and E. W. Strauss. Some species differences in the intrinsic factor stimulation of $\mathrm{B}_{12}$ uptake by small intestine in vitro. Amer. J. Physiol. 1959, 197, 926.

23. Strauss, E. W., and T. H. Wilson. Factors controlling $\mathrm{B}_{12}$ uptake by intestinal sacs in vitro. Amer. J. Physiol. 1960, 198, 103. 
24. Wolff, R., and P. Nabet. A new method for the biological determination of intrinsic factor in human gastric juice. Results obtained in normals and in pernicious anemia patients in Vitamin $\mathrm{B}_{12}$ and Intrinsic Factor, H. C. Heinrich, Ed. Stuttgart, Ferdinand Enke, 1962, p. 514.

25. Boass, A., and T. H. Wilson. An assay for gastric intrinsic factor. Amer. J. Physiol. 1963, 204, 97.

26. Sullivan, L. W., V. Herbert, and W. B. Castle. In vitro assay for human intrinsic factor. Clin. Res. 1962, 10, 208.

27. Coates, M. E., and E. S. Holdsworth. The mechanism of vitamin $B_{12}$ absorption in animals. Clin. chim. Acta 1961, 6, 44.

28. Okuno, A., and D. Miller. Kinetics of $B_{12}$ uptake in preparations of hamster intestine. J. Lab. clin. Med. 1962, 60, 1002.

29. Science and the citizen (editorial). Scientific American 1962, 207(2), 56.

30. Dawson, A. M., and K. J. Isselbacher. The esterification of palmitate-1-C ${ }^{14}$ by homogenates of intestinal mucosa. J. clin. Invest. 1960, 39, 150.

31. The National Formulary, 11th ed. Easton, Pa., Mack Printing Co., 1960.

32. Kay, A. W. Effect of large doses of histamine on gastric secretion of $\mathrm{HCl}$; an augmented histamine test. Brit. med. J. 1953, 2, 77.

33. Cohen, P. P. Suspending media for animal tissues in Manometric Techniques, 3rd ed., W. W. Umbreit, R. H. Burris, and J. F. Stauffer, Eds. Minneapolis, Burgess, 1957, p. 149.

34. Gomori, G. Histochemical demonstration of sites of choline esterase activity. Proc. Soc. exp. Biol. (N. Y.) $1948,68,354$

35. Cooper, B. A., and W. B. Castle. Sequential mechanisms in the enhanced aborption of vitamin $B_{12}$ by intrinsic factor in the rat. J. clin. Invest. 1960, 39, 199.

36. Prusoff, W. H., A. D. Welch, R. W. Heinle, and G. C. Meacham. Concentration of intrinsic factor and vitamin $\mathrm{B}_{12}$-binding activities of fractions of dessicated hog stomach. Blood 1953, 8, 491.

37. Kaplan, M. E., R. Zalusky, J. Remington, and V. Herbert. Immunologic studies with intrinsic factor in man. J. clin. Invest. 1963, 42, 368.

38. Castro, Z., V. Herbert, and L. Wasserman. Blocking of hog intrinsic factor by human gastric juice and certain mucopolysaccharides, including blood group substance. J. clin. Invest. 1961, 40, 66 .

39. Goldhamer, S. M. The presence of the intrinsic factor of Castle in the gastric juice of patients with pernicious anemia. Amer. J. med. Sci. 1936, 191, 405.

40. Callender, S. T., and G. H. Spray. Latent pernicious anemia. Brit. J. Haemat. 1962, 8, 230.

41. McIntyre, P. A., R. Hahn, C. L. Conley, and B. Glass. Genetic factors in predisposition to pernicious anemia. Bull. Johns Hopk. Hosp. 1959, 104, 309.

42. Glass, G. B. J., Z. Castro, H. Uchino, G. Schwartz, $\mathrm{A}$. Ishimori, and $\mathrm{P}$. Morkin. In vitro test on gastric juice for pernicious anemia and its precursor states in Vitamin $\mathrm{B}_{12}$ and Intrinsic Factor, H. C. Heinrich, Ed. Stuttgart, Ferdinand Enke, 1962, p. 520.

43. Grasbeck, R. Studies on the Vitamin $B_{12}$-binding principle and other biocolloids of human gastric juice. Acta med. scand. 1956, 154, suppl. 314.

44. Castro, Z. Letter to V. Herbert, December 22, 1961. 45. Herbert, V. Letter to Z. Castro, December 26, 1961.

46. Castro, Z., and G. B. J. Glass. Guinea pig intestinal mucosa homogenate system (GPIMH) for assay of I. F. activity. Clin. Res. 1962, 10, 197.

47. Castro-Curel, Z., and G. B. J. Glass. Assay of intrinsic factor activity on guinea pig intestinal mucosa homogenate. Proc. Soc. exp. Biol. (N. Y.) $1963,112,715$.

48. Hunt, J. N. An interpretation of the histamine test of gastric secretion. Gastroenterology 1950, 16, 231.

49. Hirschowitz, B. I., J. L. London, and H. M. Pollard. Histamine stimulation of gastric pepsin secretion in man. Gastroenterology 1957, 32, 85.

50. Friedman, E., I. Poliner, and H. M. Spiro. Effect of histamine on gastric pepsin secretion in man. New Engl. J. Med. 1957, 257, 901.

51. Fattah, F., W. O. Griffen, Jr., D. M. Nicoloff, A. Castaneda, and O. H. Wangensteen. Factors which effect release of pepsinogen granules from gastric tubules. Surgery 1961, 49, 593.

52. Keuning, F. J., A. Arends, E. Mandema, and H. O. Nieweg. Observations on the site of production of Castle's intrinsic factor in the rat. J. Lab. clin. Med. 1959, 53, 127. 